\title{
Initiation and elongation steps of mRNA translation are involved in the increase in milk protein yield caused by growth hormone administration during lactation
}

\author{
A. A. Hayashi, ${ }^{\star} †$ K. Nones, ${ }^{*}$ N. C. Roy, ${ }^{*}$ W. C. McNabb, ${ }^{*}$ D. S. Mackenzie, † D. Pacheco, ${ }^{*}$ and S. McCoard ${ }^{* 1}$ \\ ${ }^{*}$ Food, Metabolism and Microbiology Section, Food and Textiles Group, AgResearch Grasslands, Tennent Drive, Palmerston North 4442, \\ New Zealand \\ †Institute of Food Nutrition and Human Health, Massey University, Tennent Drive, Palmerston North 4442, New Zealand
}

\begin{abstract}
The underlying molecular mechanisms that control milk yield and milk protein yield in domestic animals are not completely understood. In this study, the galactopoietic response to exogenous growth hormone $(\mathrm{GH})$ was used as an experimental model to investigate the role of translation initiation and elongation in the regulation of milk protein synthesis in the mammary gland. A slow-release formula of commercially available GH was administered via a single subcutaneous injection to 4 lactating cows (GH group). A further 4 cows were given a single subcutaneous injection of saline (control group). Changes in mRNA transcript level and protein phosphorylation status of key members of the mammalian target of rapamycin (mTOR) pathway were assessed in mammary gland tissues of these animals using quantitative real-time PCR and Western blotting. The GH treatment enhanced the phosphorylation of ribosomal protein S6 and increased the protein abundance of eukaryotic initiation factor $4 \mathrm{E}$ (eIF4E) and eukaryotic elongation factor 2 (eEF2) proteins in the mammary gland of GH-treated animals. These results indicate a link between milk protein synthesis and the regulation of mRNA translation. The GH treatment did not change mRNA abundance of ribosomal protein S6, eIF4E, and eEF2, nor did it change the mRNA (mTOR, eEF2 kinase) or protein abundance of eEF2 kinase. These results demonstrate that GH administration changes mRNA translation initiation and elongation possibly via the mTOR pathway (suggested by the increased levels of ribosomal protein S6 phosphorylation), indicating that the mTOR pathway might be a potential control point in the regulation of milk protein synthesis in the mammary gland.
\end{abstract}

Key words: growth hormone, mammary gland, bovine, gene expression

Received May 6, 2008.

Accepted December 4, 2008.

${ }^{1}$ Corresponding author: sue.mccoard@agresearch.co.nz

\section{INTRODUCTION}

Milk, especially milk protein, is an important source of nutrition for humans and production needs to increase to match global demand (Huffman and Harper, 1999). The composition and yield of milk protein is tightly regulated and varies widely among animals (Jenness, 1979). Growth hormone (GH) has a well-established galactopoietic effect on the bovine mammary gland (Bauman et al., 1985; Molento et al., 2002); however, the molecular mechanisms mediating the effect of $\mathrm{GH}$ on protein synthesis in the bovine mammary gland remain largely unknown. Several studies have shown that the positive effects of $\mathrm{GH}$ on lactation are related to increases in the proliferation and activity of mammary epithelial cells (Berry et al., 2001; Molento et al., 2002) as a result of either the direct effect of GH on the mammary gland or an indirect effect via increased secretion of IGF-1 (Akers et al., 2000; Allan et al., 2002).

Previous studies have indicated that the regulation of protein translation may be important in regulating milk production (Long et al., 2001b; Toerien and Cant, 2007); however, the importance of translational regulation and the effect on milk protein synthesis during established lactation has not been studied. In many tissues (muscle, liver, adipose tissue) GH influences protein metabolism through changes in the protein translation machinery (Bush et al., 2003), specifically changes in the mammalian target of rapamycin (mTOR) signaling pathway (Hayashi and Proud, 2007). These observations suggest that the mTOR may mediate the effects of GH in the bovine mammary gland.

The GH signaling cascade involves the binding of GH to its receptor, followed by the phosphorylation and activation of janus kinase 2 (JAK2). In turn, JAK2 triggers a cascade of signaling events that involve the insulin receptor substrate (IRS), followed by the phosphoinositide 3-kinase (PI 3-kinase) and protein kinase B (PKB; Souza et al., 1994; Carter-Su et al., 1996; Costoya et al., 1999; Harrington et al., 2005). Similar to GH, IGF-I also acts through an IRS cascade (LeRoith 
Table 1. Milk yield and composition in control and growth hormone (GH)-treated cows after $6 \mathrm{~d}$ of treatment

\begin{tabular}{lcccc}
\hline Item & Control & GH & SEM & $P$-value \\
\hline Cows (n) & 4 & \multicolumn{1}{c}{4} & & \\
Yield parameters (kg/d) & & & & \\
$\quad$ Milk & 8.24 & 11.69 & 0.69 & $<0.01$ \\
Protein & 0.35 & 0.50 & 0.03 & $<0.01$ \\
Fat & 0.54 & 0.74 & 0.04 & $<0.01$ \\
$\quad$ Lactose & 0.43 & 0.61 & 0.04 & $<0.01$ \\
Composition (\%) & & & & \\
Protein & 4.36 & 4.20 & 0.13 & 0.39 \\
$\quad$ Fat & 6.58 & 6.32 & 0.27 & 0.49 \\
Lactose & 5.23 & 5.19 & 0.05 & 0.61 \\
\hline
\end{tabular}

et al., 1995) and it is likely to account for some of the GH effects in the mammary mTOR signaling (Cui et al., 2003). Protein kinase B directly phosphorylates tuberous sclerosis complex-2 (TSC2) in response to GH treatment inducing the activation of mTOR (Hayashi and Proud, 2007). The activation of the mTOR signaling cascade ultimately affects the cellular protein synthetic machinery through changes in the phosphorylation status of eukaryotic initiation factor $4 \mathrm{E}$ ( $\mathbf{e I F} 4 \mathbf{E})$ binding protein (4E-BP1), and ribosomal protein $\mathrm{S} 6$ kinase (S6K). Dephosphorylation of 4E-BP1 prevents eIF4E from binding eIF4G to form complexes that are competent for cap-dependent mRNA translation. Phosphorylated S6K activates several proteins including eukaryotic elongation factor 2 kinase $(\mathbf{e E F} 2 \mathbf{K})$, eukaryotic initiation factor 4B, and ribosomal protein S6, and therefore affects initiation and elongation stages of mRNA translation. Eukaryotic elongation factor 2 kinase is a specific kinase that phosphorylates the elongation factor 2, which inhibits the elongation phase of protein synthesis (Browne and Proud, 2002). Recently it was reported that GH treatment of bovine mammary epithelial cells in vitro induces phosphorylation of PKB (also termed Akt; Sakamoto et al., 2007). The established linkage between GH activation of PKB and downstream activation of the mTOR pathway (Hayashi and Proud, 2007) further suggests the potential involvement of the mTOR pathway in the regulation of milk protein synthesis in the mammary gland.

Although the role of the translation factors in the overall control of protein synthesis has been studied extensively in many tissues, the role of these factors in the mammary gland has only recently received attention. Phosphorylation of ribosomal protein S6 in the mammary gland is greater in lactating cows compared with nonlactating animals (Toerien and Cant, 2007), and eIF4E has been implicated in mammary gland development and the onset of lactation (Long et al., 2001a,b). A close linear relationship has also been reported between the amount of eEF2 (phosphorylation status of eEF2 was not evaluated in this study) in the mammary gland at the end of lactation and the amount of protein and casein output in milk (Christophersen et al., 2002). Collectively these studies suggest that translation initiation and elongation factors could be potential targets for the regulation of milk production and thus potentially milk protein synthesis.

The aim of this study was to establish the role of translation initiation and elongation factors in mediating the effects of GH on milk protein synthesis, specifically the role of the mTOR translational regulatory pathway.

\section{MATERIALS AND METHODS}

\section{Animals and Milk Composition}

All procedures involving animals were carried out in compliance with the guidelines of the AgResearch Grasslands Animal Ethics Committee (Palmerston North, New Zealand). The trial involved 8 nonpregnant, second-lactation spring-calved Jersey cows (189 $\pm 11 \mathrm{~d}$ postpartum), fed with a diet formulated to exceed requirements for ME and MP and essential amino acids (good-quality pasture balage: 11.5 MJ of ME/ $\mathrm{kg}$ of DM, $45 \%$ DM content, offered at $14 \mathrm{~kg} / \mathrm{cow}$ per day, plus a concentrate milking cow ration: $11.5 \mathrm{MJ}$ of $\mathrm{ME} / \mathrm{kg}$ of DM, $90 \%$ DM content offered at $3 \mathrm{~kg} / \mathrm{cow}$ per day). The cows were fed at 0700, 1600, and $2000 \mathrm{~h}$, with fresh water available ad libitum. Cows were housed indoors in separate stalls throughout the experiment and were acclimated to indoor housing and concentrate feeding conditions for $2 \mathrm{wk}$ before the experiment. All cows were milked at 0730 and $1630 \mathrm{~h}$, milk yield was recorded (Table 1), and samples were collected at each milking for measurement of milk composition (Table 1). Milk was analyzed for protein, fat, lactose, and SCC by the milk analysis laboratory of Livestock Improvement Corp. (Hamilton, New Zealand).

A slow-release formula of commercially available GH (Lactatropin, Elanco Animal Health, Bryanston, South Africa) was administered via a single subcutaneous injection to 4 lactating cows (GH group). A further 4 cows were given a single subcutaneous injection of saline (control group). Six days following injection, all animals were killed using an overdose of sodium pentobarbitone (Provet NZ, Auckland, New Zealand). Mammary gland samples from the right hind quarter were collected and snap frozen in liquid nitrogen within 5 min postmortem and stored at $-85^{\circ} \mathrm{C}$ for RNA and protein analyses.

Blood samples for the circulating concentrations of IGF-I in the GH group and control group were taken from each cow before each milking on $\mathrm{d} 0$ and on $\mathrm{d}$ 
Table 2. Gene name, GenBank accession number, forward and reverse primer sequences $\left(5^{\prime} \rightarrow 3^{\prime}\right)$, and quantitative real-time-PCR product length (amplification size)

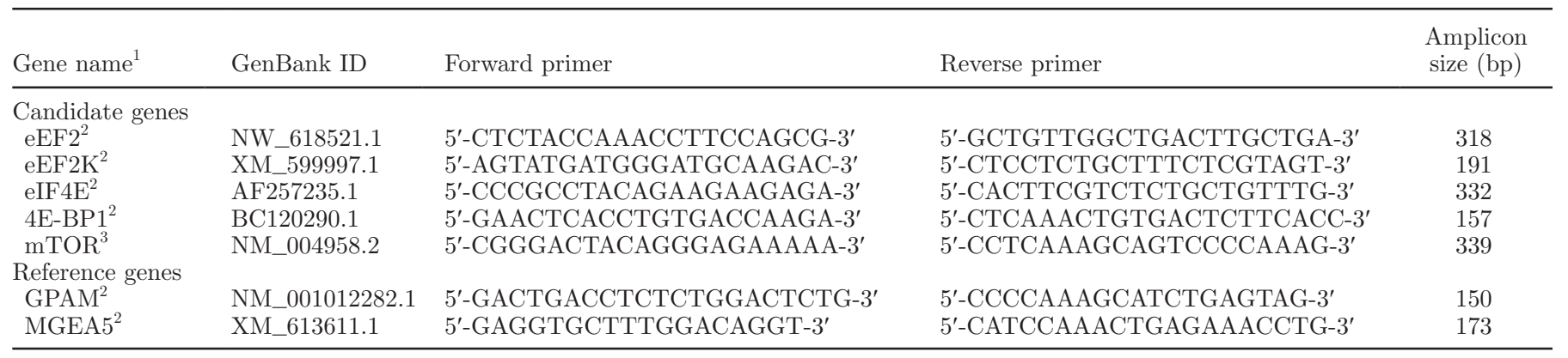

${ }^{1} \mathrm{eEF} 2$ = eukaryotic elongation factor 2 ; eEF2K = eukaryotic elongation factor 2 kinase; eIF4E = eukaryotic initiation factor $4 \mathrm{E}$; $4 \mathrm{E}-\mathrm{BP} 1=$ eukaryotic initiation factor $4 \mathrm{E}$ binding protein; $\mathrm{mTOR}=$ mammalian target of rapamycin; GPAM $=$ glycerol-3-phosphate acyltransferase, mitochondrial; MGEA5 = meningioma-expressed antigen 5 .

${ }^{2}$ Bos taurus sequence.

${ }^{3}$ Homo sapiens sequence; the human mTOR sequence used had $>99 \%$ homology with bovine.

1, 4, and 6 following GH treatments. Levels of IGF-I were evaluated using the DSL-2800 Active nonextraction IGF-I coated-tube 2-side immunoradiometric assay (Diagnostic Systems Laboratories Inc., Webster, TX; Miles et al., 1974).

Milk yields, SCC, and hormone concentrations were analyzed using the Mixed procedure in SAS Version 9.3 (SAS Institute, Cary, NC). Measurements made before the GH administration (i.e., d 0) were used as covariates in their respective analysis. A linear model was used that included treatment and day effects and their interaction. Day effects were treated as repeated measurements in time using cows within treatment as the measurement subjects (Littell et al., 1998). Several variance-covariance structures were fitted to the repeated measurement and a first-order autoregressive matrix was deemed to provide the best fit for the residual covariance structure of the repeated measurements over time within animals, according to both the Bayesian and Akaike's information criteria. Data are presented as least squares means and standard errors of the mean (SEM). Probability values $<0.05$ were considered statistically significant.

\section{Total RNA Extraction}

Total RNA was extracted from $300 \mathrm{mg}$ of frozen mammary tissue from control and GH-treated animals using TRIzol reagent (Invitrogen, Auckland, New Zealand). This and all subsequent steps were performed as recommended by the manufacturer. A subsequent purification step was carried out using RNeasy columns (Qiagen, San Diego, CA) and DNase I (Invitrogen) to remove any residual DNA contamination. RNA was quantified using a NanoDrop Spectrophotometer ND1000 (Nanodrop Technologies, Wilmington, DE), and
RNA quality was examined using a RNA 6000 LabChip Kit and 2100 Bioanalyser (Agilent Technologies, Santa Clara, CA). The ratio of the optical density at $260 \mathrm{~nm}$ to that at $280 \mathrm{~nm}$ exceeded 1.8 for all RNA samples.

\section{Quantitative Real-Time PCR}

Quantitative real-time PCR (qRT-PCR) analysis was used to quantify the expression of specific genes (Table 2). Complementary DNA was synthesized using Transcriptor First Strand cDNA Synthesis Kit (Roche Diagnostics, Mannheim, Germany). Reverse transcription was performed using $0.6 \mu \mathrm{g}$ of total RNA and oligo-dT primers according to the manufacturer's instructions. The PCR conditions were $95^{\circ} \mathrm{C}$ for $10 \mathrm{~min}$, 40 cycles at $95^{\circ} \mathrm{C}$ for $15 \mathrm{~s}, 55^{\circ} \mathrm{C}$ to $67^{\circ} \mathrm{C}$ (primer-specific optimal annealing temperature) for $15 \mathrm{~s}$, and $72^{\circ} \mathrm{C}$ for $20 \mathrm{~s}$. Melting curve analysis was performed by increasing the temperature $\left(1^{\circ} \mathrm{C} / \mathrm{s}\right)$ from 65 to $95^{\circ} \mathrm{C}$ with continuous fluorescence acquisition.

Primers for the target genes eEF2, eEF2K, eIF4E, 4E-BP1, and mTOR were designed with Primer 3.0 (Rozen and Skaletsky, 2000) using publicly available sequences. The PCR conditions for all primers were optimized and amplicons were sequenced to confirm identity. Specificities of all reactions were verified by melting curves and electrophoresis on 1\% agarose gels. Primers for target genes and 2 reference genes are shown in Table 2.

Threshold cycle (CT) values were obtained in triplicate for each sample on the Light Cycler (Roche Diagnostics) using LightCycler FastStart DNA Master plus SYBR Green I (Roche Diagnostics) according to the manufacturer's protocol. The mean of 3 replicates was used for the statistical analyses. The efficiencies of PCR for each set of primers were calculated for each 
sample using the LineReg PCR program (Ramakers et al., 2003). The differences in expression between control and treated group means were assessed for statistical significance by pair-wise fixed reallocation randomization test, using the relative expression software tool (REST; Pfaffl et al., 2002). An index (part of the REST program) was generated with 2 reference genes selected: glycerol-3-phosphate acyltransferase and mitochondrial and meningioma-expressed antigen 5. These genes were not differentially expressed in the mammary gland of either GH-treated or control cows (assessed by qRTPCR, data not shown), and the index generated with their values was used to normalize the data. Probability $<0.05$ was considered statistically significant.

\section{SDS-PAGE and Western Blotting}

For Western blotting analysis, $300 \mathrm{mg}$ of frozen tissue from individual animals was lysed in extraction buffer (Kimball et al., 1996). Lysates were centrifuged at $13,000 \times g$ for $10 \mathrm{~min}$ to remove debris, and the protein concentrations in the resulting supernatants were determined as described by Bradford (1976). Aliquots of lysate containing equal amounts of protein were used for SDS-PAGE and Western blotting, which were performed as described earlier (Kimball et al., 1996); however, different exposure times were required for different proteins to obtain better results. For total ribosomal protein S6, phospho-S6 (Ser235/236), total $4 \mathrm{E}-\mathrm{BP} 1$, and total eIF4E, exposure times were between 5 and 10 s. For phospho-4E-BP1 (Thr70), a 5-min exposure was required. A 1-min exposure was used for total eEF2K, phospho-eEF2K (Ser366), total eEF2, and phospho-eEF2 (Thr56). Blots were visualized using the enhanced chemiluminescence method. Immobilon P membranes were purchased from Millipore (Billerica, $\mathrm{MA}$ ), and enhanced chemiluminescence reagents were purchased from Amersham Biosciences (GE Healthcare, Buckinghamshire, UK). Other chemicals were purchased from Sigma unless otherwise stated. Primary antibodies against total ribosomal protein S6, phospho-S6 (Ser235/236), total 4E-BP1, phospho-4E-BP1 (Thr70), total eEF2K, phospho-eEF2K (Ser366), total eEF2, phospho-eEF2 (Thr56), and total eIF4E were purchased from Cell Signaling Technology (Beverly, MA). Horseradish peroxidase-conjugated goat anti-rabbit secondary antibody was obtained from Amersham Biosciences (Piscataway, NJ). Each blot was generated at least 3 times with similar outcomes, and the graphs show the densitometry (mean \pm SE for 4 animals/treatment). Triplicate blots were averaged for each cow and then averaged across cows within the treatments. Image/J software (available at rsb.info.nih.gov/ij/) was used for quantification where indicated. In the case of Western blotting, data from a typical blot are shown. All data comparisons were analyzed for statistical significance using $t$-test. Differences were considered significant at a probability value $<0.05$.

\section{RESULTS}

\section{Milk Yield, Milk Composition, and Hormone Concentration}

Mean daily milk and protein production for all cows before treatment (mean $\pm \mathrm{SE}$ ) was $8.5 \pm 1.17 \mathrm{~L} /$ cow and $0.47 \pm 0.055 \mathrm{~kg} / \mathrm{cow}$, respectively. There were significant differences between $\mathrm{GH}$ and control groups in milk (Figure 1A) and protein (Figure 1B) yields by d 4 of GH treatment. Six days after treatment, GH had increased milk yield by $42 \%$ compared with controls, with corresponding increases in protein, fat, and lactose yields (Table 1). Somatic cell analyses showed that there were no significant differences between treatments and there were no significant differences within each day (data not shown).

The serum concentrations of IGF-1 on $\mathrm{d} 4$ and 6 of $\mathrm{GH}$ administration were significantly $(P<0.001)$ higher for the GH group compared with controls (GH: $928.0 \pm 26.6$ and $582.0 \pm 64.2 \mathrm{ng} / \mathrm{mL}$; control: $196.0 \pm$ 26.6 and $74.0 \pm 64.2 \mathrm{ng} / \mathrm{mL}$, respectively), indicating that the dosing and timing protocol for GH treatment was successful.

\section{Effect of GH Treatment on mRNA Abundance}

Treatment with GH did not change the mRNA levels of the translation factors studied (Figure 2). Figure 2 illustrates the CT values for each animal (black dots) and the average for each group (line) for visualization. These findings suggest that the effect of GH on mammary gland protein synthesis was not mediated through an effect on the expression (mRNA levels) of genes in the initiation and elongation stages of translation. Therefore, further assessment of the expression of other genes in the translational machinery was not pursued.

\section{Effect of GH Treatment on Total Ribosomal Protein S6 and Phospho-S6}

Ribosomal protein S6 has been suggested to play an important role in the translation of ribosomal mRNA sequences. The total protein abundance of ribosomal protein S6 in the mammary gland was not changed in response to GH treatment (percentage of treatment in relation to control: $103 \pm 6$ vs. $100 \pm 15 ; P=0.86$ for the GH and control groups, respectively; Figure 3). However, the phosphorylation of ribosomal protein $\mathrm{S} 6$ 

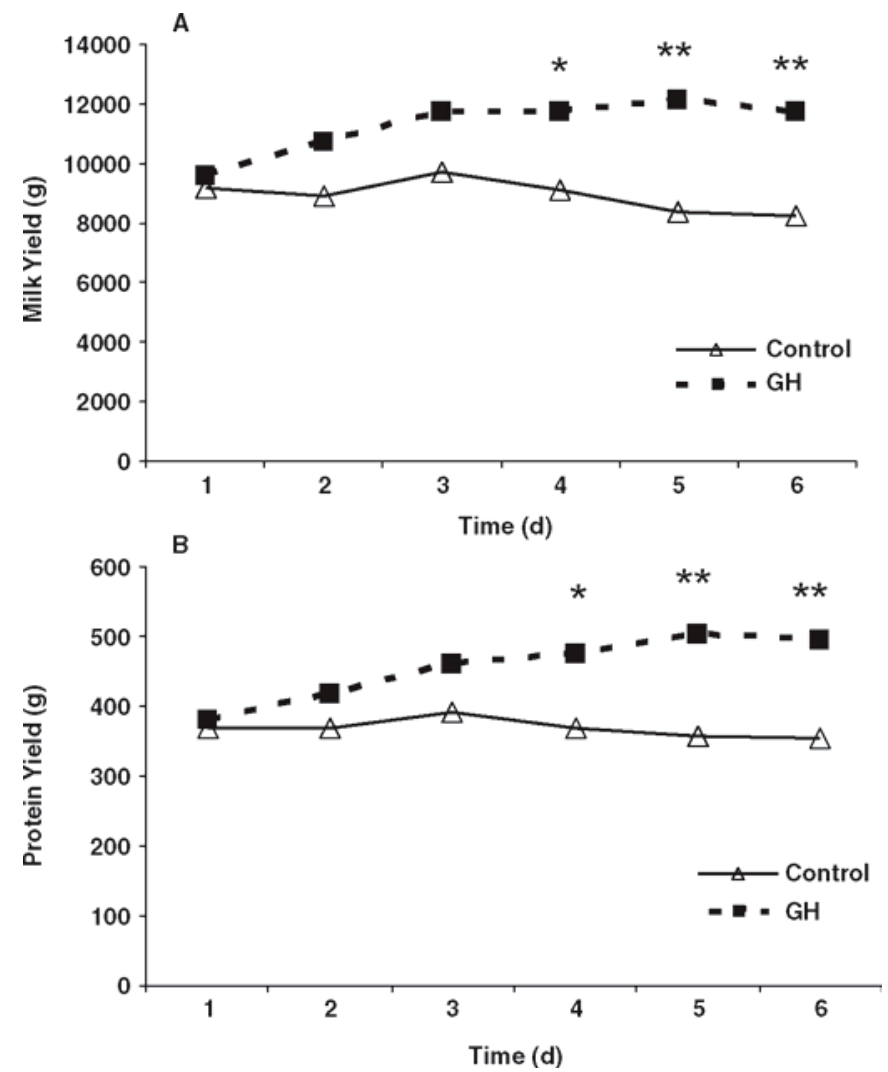

Figure 1. Least squares mean daily milk yield (A) and protein yield (B) in control and growth hormone $(\mathrm{GH})$-treated cows over $6 \mathrm{~d}$ following the injection of a slow-release formulation of $\mathrm{GH}$ on $\mathrm{d} 0 .{ }^{*} P$ $<0.05 ;{ }^{* *} P<0.05$.

at Ser235/236 was increased by GH treatment (percentage of treatment in relation to control: $278 \pm 16$ vs. $100 \pm 18 ; P<0.001$, for the GH and control groups, respectively; Figure 3).

\section{Effect of GH Treatment on Total 4E-BP1, Phospho-4E-BP1, and Total elF4E}

The nonphosphorylated protein 4E-BP1 negatively regulates eIF4F assembly by sequestering its mRNA cap-binding component eIF4E, whereas hyperphosphorylation abrogates this function (Gingras et al., 1999). The protein abundance of $4 \mathrm{E}-\mathrm{BP} 1$ in the mammary gland was not affected by GH treatment (percentage of treatment in relation to control: $80 \pm 12$ vs. $100 \pm 5$; $P=0.20$, for the $\mathrm{GH}$ and control groups, respectively; Figure 4). The phosphorylation status of the 4E-BP1 at Thr70 (percentage of treatment in relation to control: $242 \pm 60$ vs. $100 \pm 20 ; P=0.08$, for the GH and control group, respectively) was also unaffected by GHtreatment (Figure 4). Treatment with GH substantially increased the protein abundance of eIF4E (percentage of treatment in relation to control: $229 \pm 18$ vs. 100 $\pm 118, P<0.01$, for the GH and control group, respectively; Figure 4). Because eIF4E is rate-limiting in translation, increased milk protein synthesis in response to GH treatment may have been associated with increased availability of eIF4E.

\section{Effect of GH on Total and Phospho eEF2 and eEF2K}

To examine the effects of GH on the elongation phase of protein synthesis, the protein abundance of eEF2 and eEF2K and the phosphorylation status of eEF2 at Thr56 and eEF2K at Ser366 were analyzed by immunoblotting. Phosphorylation of eEF2K at Ser366 is rapamycin sensitive, and phosphorylation of this site inactivates eEF2K (Browne and Proud, 2004). The phosphorylation of eEF2 at Thr56 inhibits its activity and consequently decreases the speed of the protein synthetic machinery. The protein abundance and phosphorylation status of eEF2K in the mammary gland were not affected by the GH treatment (Figure 5). In contrast, GH treatment significantly increased the protein abundance of eEF2 (percentage of treatment in relation to control: $180 \pm 8$ vs. $100 \pm 9, P<0.01$, for the GH and control group, respectively) and also caused changes in the phosphorylation status of eEF2 at Thr 56 (percentage of treatment in relation to control: $36 \pm 12$ vs. $100 \pm 19, P=0.05$, for the GH and control group, respectively, Figure 5).

\section{DISCUSSION}

The findings from the current study provide new evidence of the molecular mechanisms mediating the effects of GH on increasing milk protein synthesis and milk and protein yield in lactating dairy cows observed here and in other studies (Bauman, 1999). As reported in previous short-term studies (Etherton and Bauman, 1998), increased milk production occurred without any change in feed intake (data not shown), supporting the hypothesis that an increased repartitioning of nutrients to the mammary gland or more efficient utilization of nutrients by the mammary gland was implicated in the effect of GH on milk production. The present study provides evidence that the effect of GH on milk production is mediated, at least in part, by upregulating the initiation and elongation phases of protein translation and suggests that mRNA translation step is associated with milk protein synthesis in the lactating cow treated with GH.

Here we show that increased milk protein yield in the GH-treated cows was associated with increased phosphorylation of ribosomal protein S6, suggesting that the effects of GH on lactation may be mediated via the 

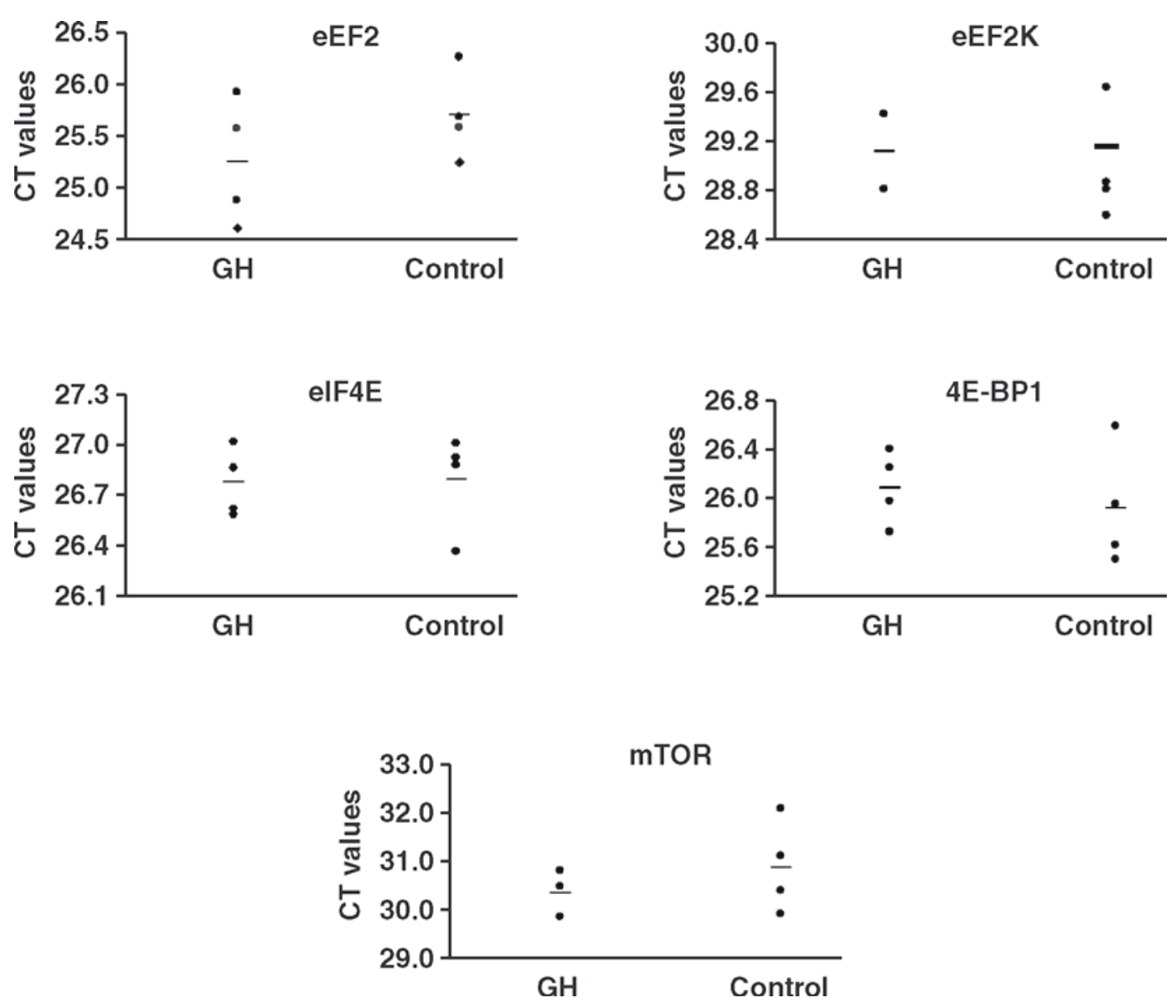

Figure 2. Quantitative real-time PCR (qRT-PCR) results of growth hormone (GH)-treated and control animals. Total mammary gland RNA from GH-treated and control animals was subjected to qRT-PCR analysis. Cycles to threshold (CT) values for individual animals (@) is shown for each treatment ( $\mathrm{GH}$ and control). In some figures, some animals had the same CT value so fewer than 4 data points (-) are visible. The horizontal line (-) indicates the average gene expression within each treatment group. Genes are as defined in Table 2.

mTOR pathway. Phosphorylation of ribosomal protein S6 correlates with increased protein synthesis (Jastrzebski et al., 2007) and it was proposed that this effect was via modulation of the uninterrupted stretch of pyrimidine residues (TOP motif) at the $5^{\prime}$ end of the mRNA. The TOP mRNA sequences encode proteins involved in mRNA translation such as translation factors and ribosomal proteins (Kimball, 2002). This would explain the increase in milk protein observed in the GH treated cows in this study. However, different studies (Ruvinsky et al., 2005; Pende, 2006; Ruvinsky and Meyuhas, 2006) have questioned the role of the ribosomal protein $\mathrm{S} 6$ in the regulation of $5^{\prime}$ TOP mRNA translation and it is suggested that phosphorylated ribosomal protein $\mathrm{S} 6$ is not necessary for $5^{\prime} \mathrm{TOP}$ mRNA regulation and it is possible that other mTORC1 target(s) may be responsible for this, which requires further investigation. The potential importance of the mTOR pathway, and notably ribosomal protein S6, on milk protein synthesis in the bovine mammary gland is supported by the observations of Toerien and Cant (2007) in which increased abundance and phosphorylation of ribosomal protein S6 coincided with the onset of lactation.

A key component in the regulation of translation initiation is eIF4E, which is the limiting component of the eIF4F initiation complex. The association of eIF4E with eIF4G is regulated in part by the phosphorylation of 4E-BP1. However, neither the relative abundance of $4 \mathrm{E}-\mathrm{BP} 1$ nor its phosphorylation was changed (Figure 4) suggesting that the GH effect on milk protein yield is not mediated by a decrease in the formation of the 4E-BP1-eIF4E complex. In contrast, the abundance of eIF4E protein in the mammary gland increased in response to GH treatment (Figure 4) suggesting an increased activation of translation initiation, which may support elevated protein synthesis. The phosphorylation of eIF4E was not measured in this study but warrants further investigation. However, the biological significance of phosphorylation of eIF4E is not completely clear. Minich et al. (1994) suggested that 
$\mathrm{GH} \quad$ Control
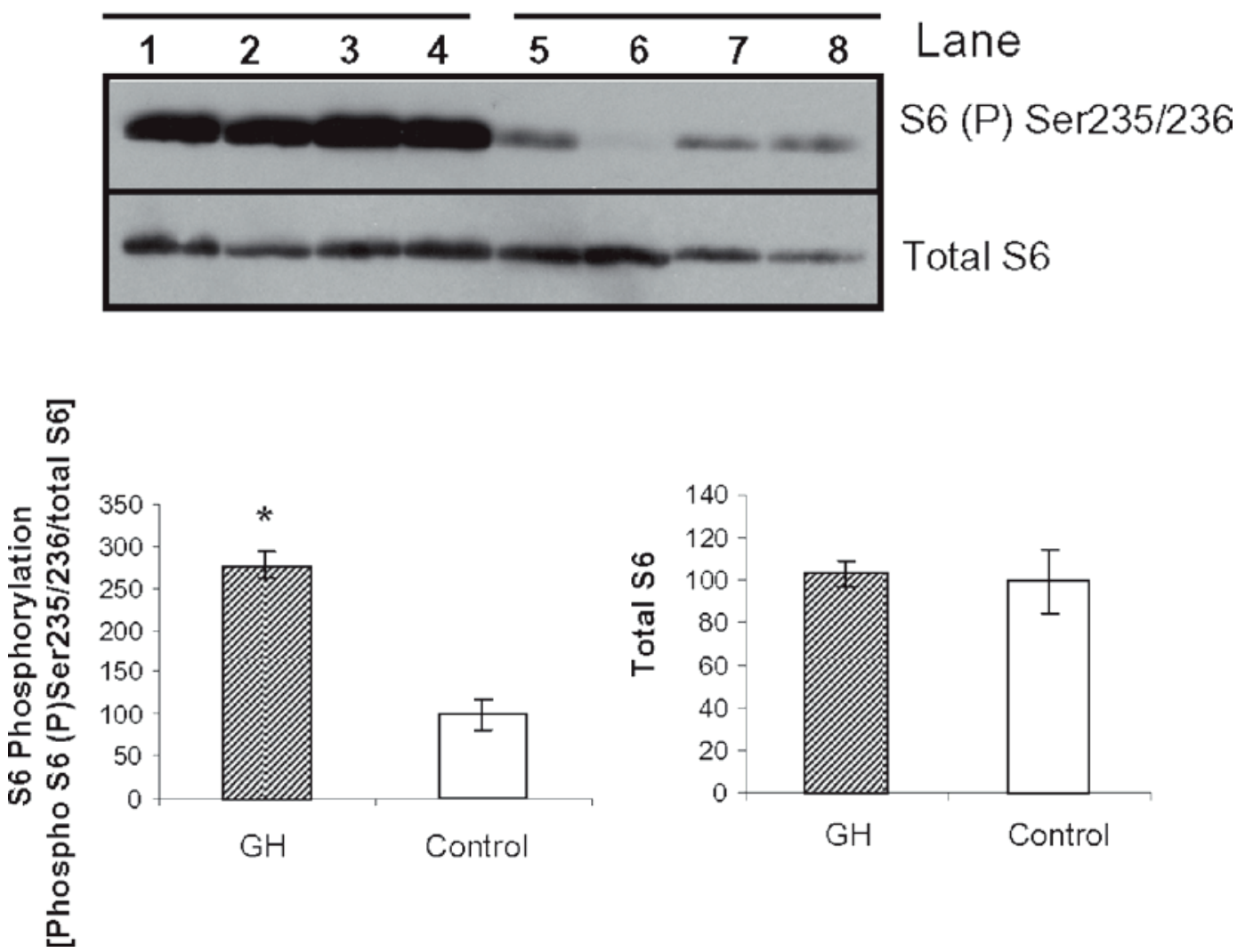

Figure 3. Growth hormone $(\mathrm{GH})$ treatment stimulated phosphorylation of ribosomal protein S6 in the mammary gland. Lactating mammary gland lysates from GH-treated and control cows were analyzed by SDS-PAGE and Western blotting using the phosphor-specific (Ser235/236) and total antisera for ribosomal protein S6. In all cases, blots represent at least 3 independent experimental replicates. The 4 lanes for GH (1 to 4 ) and the 4 lanes for control (5 to 8) represent the 4 animals/treatment used in this experiment. The graph shows the phosphorylation of ribosomal protein $\mathrm{S} 6[\mathrm{~S} 6(\mathrm{P})]$ normalized for total ribosomal protein $\mathrm{S} 6$ content in the sample (mean $\pm \mathrm{SE}, \mathrm{n}=4 /$ treatment); ${ }^{*} P<0.01$.

the phosphorylation of eIF4E enhances its binding to capped RNA, and later reports (Scheper et al., 2002; Slepenkov et al., 2006) showed that phosphorylation actually decreased its affinity for 7-methylguanosine or capped RNA.

We examined the effects of GH on translation elongation by evaluating its effect on eEF2 and its kinase, eEF2K, which is the only kinase identified that phosphorylates eEF2. The activity of eEF2K is controlled via the mTOR pathway as well as by other signaling pathways (Browne and Proud, 2004) in response to insulin and other agents (Proud, 2006). The relative phosphorylation of eEF2K, as well as the total protein abundance of eEF $2 \mathrm{~K}$ did not change in the mammary gland in response to GH (Figure 5). Similarly, the phosphorylation of eEF2 at Thr56 did not change in response to GH treatment, but an increase in the abundance of eEF2 protein was observed in GH-treated cows. A role for eEF2 protein abundance as a rate-limiting factor for milk protein synthesis in the bovine mammary gland is further supported by the observations of Christophersen et al. (2002), who reported that eEF2 levels in mammary gland tissue are 50 times higher than the levels of eEF2 found in muscle, and that there is a close linear relation between the amount of eEF2 in the mammary gland at the end of lactation and the amount of protein and casein output in milk.

The findings from this study show that GH treatment affects both the initiation and elongation stages of translation in the mammary gland of the lactating dairy cow through an increase in the levels of eIF4E and eEF2. Additionally, the effect of GH on the ribosomal protein $\mathrm{S} 6$ phosphorylation connects the increase in milk protein production with increased protein synthesis. These proteins are direct downstream targets of mTOR, which has previously been shown to mediate the effects of GH on protein synthesis in hepatic cells (Hayashi and Proud, 2007). 
$\mathrm{GH} \quad$ Control
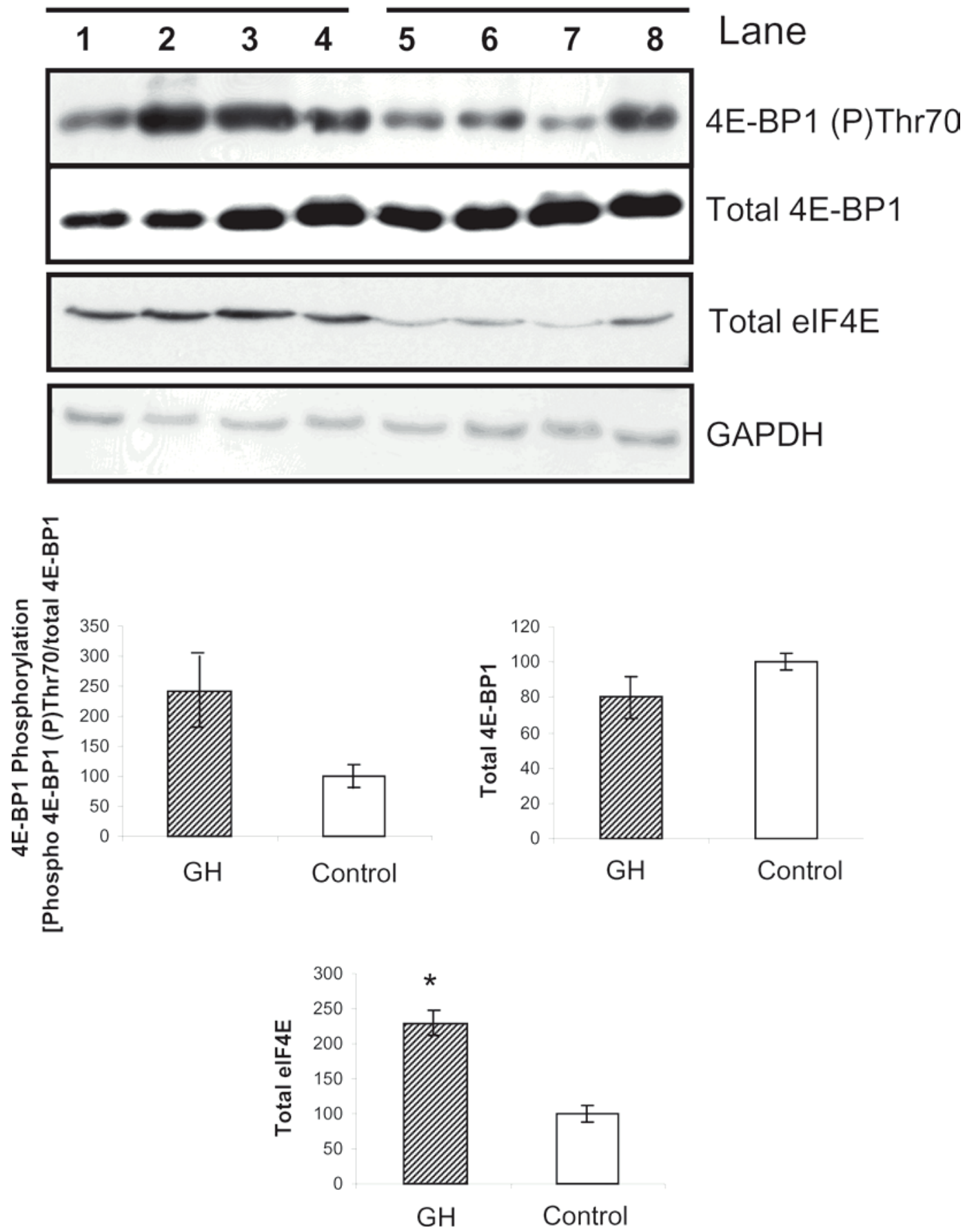

Figure 4. Growth hormone $(\mathrm{GH})$ treatment increased the protein abundance of eukaryotic initiation factor 4E (eIF4E) in the mammary gland but did not affect the phosphorylation of eIF4E binding protein 1 (4E-BP1). The graphs show the phosphorylation of 4E-BP1 (Thr70) normalized for total 4E-BP1 content in the sample and the total eIF4E normalized for total GAPDH content in the sample. In all cases, blots are representative of at least 3 experimental replicates. The 4 lanes for GH (1 to 4 ) and the 4 lanes for control (5 to 8 ) represent the 4 animals/ treatment used in this experiment. The graph shows the mean $\pm \mathrm{SE}, \mathrm{n}=4$ /treatment; ${ }^{*} P<0.01$. 
$\mathrm{GH} \quad$ Control
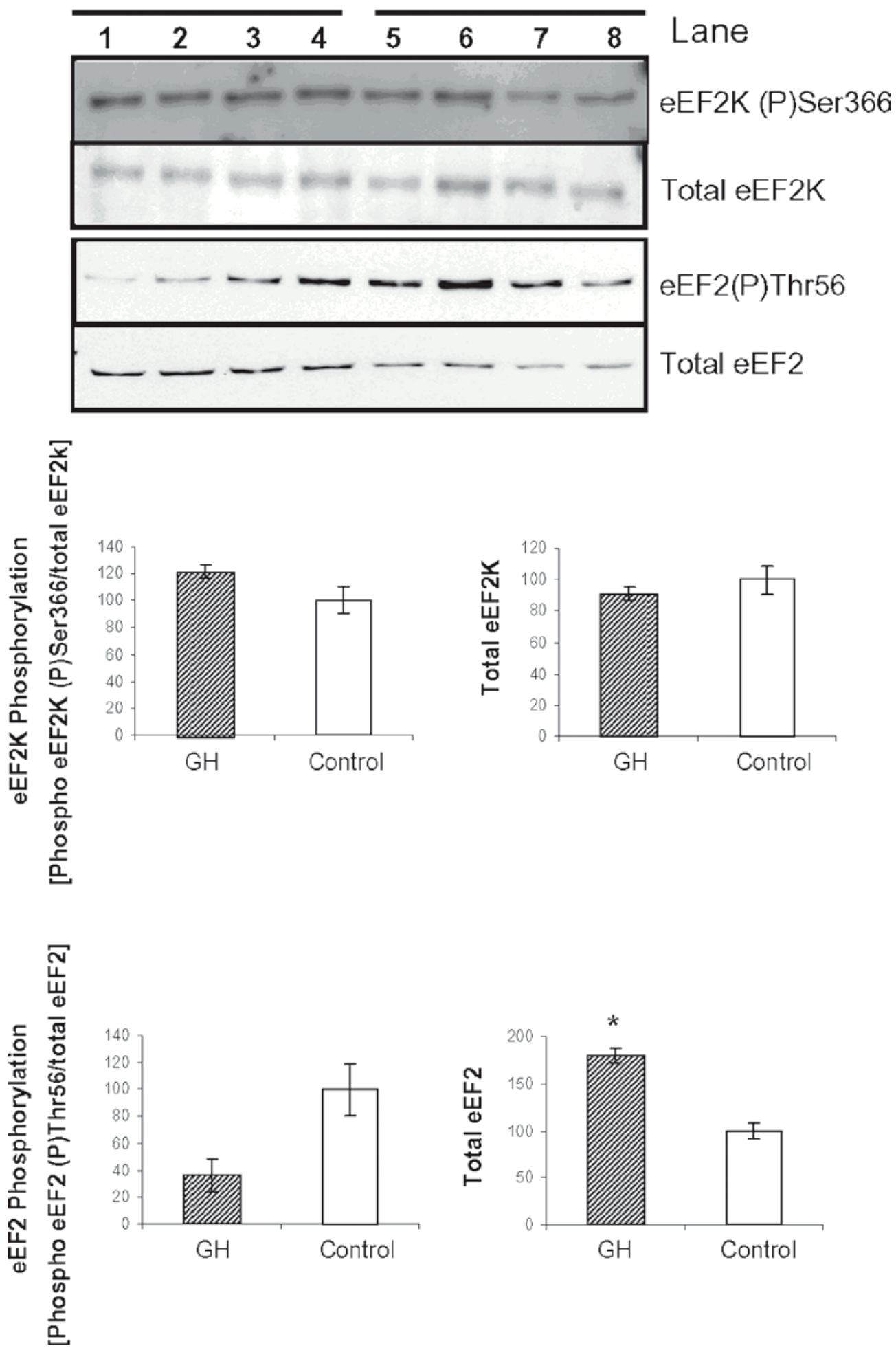

Figure 5. Growth hormone (GH) treatment changed total eukaryotic elongation factor 2 (eEF2) but did not change the phosphorylation status of eEF2 and eEF2 kinase (eEF2K). Lactating mammary gland lysates from GH-treated and control cows were analyzed by SDS-PAGE and Western blotting using the phospho-specific (Ser366) eEF2K and (Thr56) eEF2. The graph shows the phosphorylation of eEF2K (Ser366) and eEF2 (Thr56) normalized for total eEF2K and total eEF2, respectively. In all cases, blots represent at least 3 experimental replicates. The 4 lanes for GH (1 to 4) and the 4 lanes for control (5 to 8) represent the 4 animals/treatment used in this experiment. The graph shows the mean $\pm \mathrm{SE}, \mathrm{n}=4$ /treatment; ${ }^{*} P<0.01$. 


\section{CONCLUSIONS}

This study reports for the first time the importance of translation initiation and elongation in the GH-mediated effect on milk protein synthesis in the mammary gland of the dairy cow. Further studies are required to establish whether mTOR mediates the effects on translation initiation and elongation in the lactating mammary gland in response to $\mathrm{GH}$, or whether other pathways are involved.

\section{ACKNOWLEDGMENTS}

The authors thank Kate Broadley and Jason Peters (AgResearch Grasslands, New Zealand) for their immense help in the lab work. We also thank Peter Schreurs, Andrea Death, Matthew Deighton, Bruce Sinclair, Clare Reynolds, Anne-Charlotte Pupin, and Jennifer Lane (AgResearch Grasslands, New Zealand) for assistance with the animal experiment. This research was conducted as part of a joint venture between AgResearch Limited and Primary Industries Research, Victoria, Australia.

This study was funded by AgResearch Investment, a FRST Postdoctoral Fellowship (S. McCoard), the Marsden Fast Start Fund (S. McCoard), and by a CAPES PhD scholarship (A. A. Hayashi) and a CNPq postdoctoral scholarship (K. Nones) from the Federal Government of Brazil.

\section{REFERENCES}

Akers, R. M., T. B. McFadden, S. Purup, M. Vestergaard, K. Sejrsen, and A. V. Capuco. 2000. Local IGF-I axis in peripubertal ruminant mammary development. J. Mammary Gland Biol. Neoplasia 5:43-51.

Allan, G. J., E. Tonner, M. C. Barber, M. T. Travers, J. H. Shand, R. G. Vernon, P. A. Kelly, N. Binart, and D. J. Flint. 2002. Growth hormone, acting in part through the insulin-like growth factor axis, rescues developmental, but not metabolic, activity in the mammary gland of mice expressing a single allele of the prolactin receptor. Endocrinology 143:4310-4319.

Bauman, D. E. 1999. Bovine somatotropin and lactation: from basic science to commercial application. Domest. Anim. Endocrinol. $17: 101-116$.

Bauman, D. E., P. J. Eppard, M. J. DeGeeter, and G. M. Lanza. 1985. Responses of high-producing dairy cows to long-term treatment with pituitary somatotropin and recombinant somatotropin. J. Dairy Sci. 68:1352-1362.

Berry, S. D., T. B. McFadden, R. E. Pearson, and R. M. Akers. 2001. A local increase in the mammary IGF-1:IGFBP-3 ratio mediates the mammogenic effects of estrogen and growth hormone. Domest. Anim. Endocrinol. 21:39-53.

Bradford, M. M. 1976. A rapid and sensitive method for the quantitation of microgram quantities of protein utilizing the principle of proteindye binding. Anal. Biochem. 72:248-254.

Browne, G. J., and C. G. Proud. 2002. Regulation of peptide-chain elongation in mammalian cells. Eur. J. Biochem. 269:5360-5368.

Browne, G. J., and C. G. Proud. 2004. A novel mTOR-regulated phosphorylation site in elongation factor 2 kinase modulates the activity of the kinase and its binding to calmodulin. Mol. Cell. Biol. 24:2986-2997.
Bush, J. A., S. R. Kimball, P. M. O'Connor, A. Suryawan, R. A. Orellana, H. V. Nguyen, L. S. Jefferson, and T. A. Davis. 2003. Translational control of protein synthesis in muscle and liver of growth hormone-treated pigs. Endocrinology 144:1273-1283.

Carter-Su, C., A. P. King, L. S. Argetsinger, L. S. Smit, J. Vanderkuur, and G. S. Campbell. 1996. Signalling pathway of GH. Endocr. J. 43(Suppl):S65-S70.

Christophersen, C. T., J. Karlsen, M. O. Nielsen, and B. Riis. 2002. Eukaryotic elongation factor-2 (eEF-2) activity in bovine mammary tissue in relation to milk protein synthesis. J. Dairy Res. 69:205-212.

Costoya, J. A., J. Finidori, S. Moutoussamy, R. Searis, J. Devesa, and V. M. Arce. 1999. Activation of growth hormone receptor delivers an antiapoptotic signal: Evidence for a role of Akt in this pathway. Endocrinology 140:5937-5943.

Cui, X., P. Zhang, W. Deng, S. Oesterreich, Y. Lu, G. B. Mills, and A. V. Lee. 2003. Insulin-like growth factor-I inhibits progesterone receptor expression in breast cancer cells via the phosphatidylinositol 3-kinase/Akt/mammalian target of rapamycin pathway: Progesterone receptor as a potential indicator of growth factor activity in breast cancer. Mol. Endocrinol. 17:575-588.

Etherton, T. D., and D. E. Bauman. 1998. Biology of somatotropin in growth and lactation of domestic animals. Physiol. Rev. 78:745761.

Gingras, A. C., B. Raught, and N. Sonenberg. 1999. eIF4 initiation factors: Effectors of mRNA recruitment to ribosomes and regulators of translation. Annu. Rev. Biochem. 68:913-963.

Harrington, L. S., G. M. Findlay, and R. F. Lamb. 2005. Restraining PI3K: mTOR signalling goes back to the membrane. Trends Biochem. Sci. 30:35-42.

Hayashi, A. A., and C. G. Proud. 2007. The rapid activation of protein synthesis by growth hormone requires signaling through mTOR. Am. J. Physiol. Endocrinol. Metab. 292:E1647-E1655.

Huffman, L. M., and W. J. Harper. 1999. Maximizing the value of milk through separation technologies. J. Dairy Sci. 82:2238-2244.

Jastrzebski, K., K. M. Hannan, E. B. Tchoubrieva, R. D. Hannan, and R. B. Pearson. 2007. Coordinate regulation of ribosome biogenesis and function by the ribosomal protein S6 kinase, a key mediator of mTOR function. Growth Factors 25:209-226.

Jenness, R. 1979. Comparative aspects of milk proteins. J. Dairy Res. $46: 197-210$

Kimball, S. R. 2002. Regulation of global and specific mRNA translation by amino acids. J. Nutr. 132:883-886.

Kimball, S. R., L. S. Jefferson, P. Fadden, T. A. Haystead, and J. C. Lawrence Jr. 1996. Insulin and diabetes cause reciprocal changes in the association of eIF-4E and PHAS-I in rat skeletal muscle. Am. J. Physiol. 270:C705-C709.

LeRoith, D., H. Werner, D. Beitner-Johnson, and C. T. Roberts Jr. 1995. Molecular and cellular aspects of the insulin-like growth factor I receptor. Endocr. Rev. 16:143-163.

Littell, R. C., P. R. Henry, and C. B. Ammerman. 1998. Statistical analysis of repeated measures data using SAS procedures. J. Anim. Sci. 76:1216-1231.

Long, E., A. V. Capuco, and X. Zhao. 2001a. Cloning of bovine eukaryotic translation initiation factor $4 \mathrm{E}$ (eIF-4E) and its expression in the bovine mammary gland at different physiological stages. DNA Seq. 12:319-329.

Long, E., A. Lazaris-Karatzas, C. Karatzas, and X. Zhao. 2001b. Overexpressing eukaryotic translation initiation factor $4 \mathrm{E}$ stimulates bovine mammary epithelial cell proliferation. Int. J. Biochem. Cell Biol. 33:133-141.

Miles, L. E., D. A. Lipschitz, C. P. Bieber, and J. D. Cook. 1974. Measurement of serum ferritin by a 2-site immunoradiometric assay. Anal. Biochem. 61:209-224.

Minich, W. B., M. L. Balasta, D. J. Goss, and R. E. Rhoads. 1994 Chromatographic resolution of in vivo phosphorylated and nonphosphorylated eukaryotic translation initiation factor eIF-4E: Increased cap affinity of the phosphorylated form. Proc. Natl. Acad. Sci. USA 91:7668-7672.

Molento, C. F., E. Block, R. I. Cue, and D. Petitclerc. 2002. Effects of insulin, recombinant bovine somatotropin, and their interaction on 
insulin-like growth factor-I secretion and milk protein production in dairy cows. J. Dairy Sci. 85:738-747.

Pende, M. 2006. mTOR, Akt, S6 kinases and the control of skeletal muscle growth. Bull. Cancer 93:E39-E43.

Pfaffl, M. W., G. W. Horgan, and L. Dempfle. 2002. Relative expression software tool (REST) for group-wise comparison and statistical analysis of relative expression results in real-time PCR. Nucleic Acids Res. 30:e36.

Proud, C. G. 2006. Regulation of protein synthesis by insulin. Biochem. Soc. Trans. 34:213-216.

Ramakers, C., J. M. Ruijter, R. H. Deprez, and A. F. Moorman. 2003. Assumption-free analysis of quantitative real-time polymerase chain reaction (PCR) data. Neurosci. Lett. 339:62-66.

Rozen, S., and H. Skaletsky. 2000. Primer3 on the WWW for general users and for biologist programmers. Methods Mol. Biol. 132:365386.

Ruvinsky, I., and O. Meyuhas. 2006. Ribosomal protein S6 phosphorylation: From protein synthesis to cell size. Trends Biochem. Sci. 31:342-348.

Ruvinsky, I. N. Sharon, T. Lerer, H. Cohen, M. Stolovich-Rain, T. Nir, Y. Dor, P. Zisman, and O. Meyuhas. 2005. Ribosomal protein S6 phosphorylation is a determinant of cell size and glucose homeostasis. Genes Dev. 19:2199-2211.
Sakamoto, K., T. Yano, T. Kobayashi, A. Hagino, H. Aso, and Y. Obara. 2007. Growth hormone suppresses the expression of IGFBP-5, and promotes the IGF-I-induced phosphorylation of Akt in bovine mammary epithelial cells. Domest. Anim. Endocrinol. $32: 260-272$.

Scheper, G. C., B. van Kollenburg, J. Hu, Y. Luo, D. J. Goss, and C. G. Proud. 2002. Phosphorylation of eukaryotic initiation factor 4E markedly reduces its affinity for capped mRNA. J. Biol. Chem. 277:3303-3309.

Slepenkov, S. V., E. Darzynkiewicz, and R. E. Rhoads. 2006. Stoppedflow kinetic analysis of eIF4E and phosphorylated eIF4E binding to cap analogs and capped oligoribonucleotides: Evidence for a one-step binding mechanism. J. Biol. Chem. 281:14927-14938.

Souza, S. C., G. P. Frick, R. Yip, R. B. Lobo, L. R. Tai, and H. M. Goodman. 1994. Growth hormone stimulates tyrosine phosphorylation of insulin receptor substrate-1. J. Biol. Chem. 269:30085-30088.

Toerien, C. A., and J. P. Cant. 2007. Abundance and phosphorylation state of translation initiation factors in mammary glands of lactating and nonlactating dairy cows. J. Dairy Sci. 90:27262734 . 